\title{
Research on modeling the technology of processing anthropogenic old tailings of Primorsky Concentrating Factory
}

\author{
Elena Shepeta ${ }^{1 *}$, Natalia Litvinova ${ }^{1}$, Marina Bubnova $^{1}$ and Mehmet Bilen $^{2}$ \\ ${ }^{1}$ Mining Institute FEB RAS, 51 Turgenev st., Khabarovsk, 680000, Russia; \\ ${ }^{2}$ Zonguldak Bulent Ecevit Universiti, Turkey
}

\begin{abstract}
The possibility of processing old tailings of the Primorsky Concentrating Factory (PCF) has been assessed. The average mass fraction of $\mathrm{WO}_{3}$ is $0.08 \%, \mathrm{Cu}$ is $0.052 \%$, the average content of $\mathrm{Au}$ is $0.38 \mathrm{ppm}$, $\mathrm{Ag}$ is $1.1 \mathrm{ppm}$. The grain size of scheelite and chalcopyrite is from 0.03 $\mathrm{mm}$ and below. Basically, intergrowths of scheelite are in quartz, less often is in pyroxene, chalcopyrite is in pyrrhotite, less often is in quartz. The results of experimental studies of the washability of secondary mineral material using flotation and gravity beneficiation methods are presented. The possibility of intensifying the flotation process of concentration using a Pneuflot ${ }^{\circledR}$ flotation machine was investigated. The recovery of scheelite at the same degree of concentration using a Pneuflot ${ }^{\circledR}$ flotation machine is $16.5 \%$ higher compared to the standard mechanical flotation machine, mainly due to the more efficient flotation $(1.5$ times $)$ of sludge $(-15+0 \mu \mathrm{m})$. Flotation of the sand fraction of old tailings (SFOT) in a Pneuflot ${ }^{\circledR}$ flotation machine showed an opportunity of scheelite recovery into enriched concentrate of rough flotation from $-44+15$ microns material by $82 \%$, and $-15+0$ microns (from sludge) by $75 \%$ of those classes, the case being for the mechanical machine (volume 31 ) - 77\% and $49 \%$ of those classes, respectively. The content of the obtained flotation concentrate corresponds to the quality of the feed of rough scheelite flotation at PCF (at a concentration degree of 8.5 in the enriched product, the scheelite recovery was $69 \%$ ), enabling to integrate it to the technological scheme of PFC. According to the combined gravity-flotation concentration scheme, a conditioned scheelite concentrate with a mass fraction of $70.9 \% \mathrm{WO}_{3}$ was obtained, throughout recovery being $57.3 \%$.
\end{abstract}

Keywords: old tailings, scheelite, chalcopyrite, flotation, washability, gravity, mineral aggregates, sludge, testing.

*Corresponding author: elenashepeta56@mail.ru 


\section{Introduction}

The decrease in the content of valuable minerals in ore at the final stages of the development of deposits necessitates an increase in the volume of processing of raw stock, an increase in the recovery of useful components while reducing the cost of obtaining commercial concentrates.

Possible directions of modernization of production facilities are the improvement of the technological scheme [1], including through the introduction of the preconcentration of the base ore [2-5], the regulation of the contrast of the flotation properties of the separated minerals [6-9], the use of new concentration devices [10,11].

At Primorsky Concentrating Factory (PCF), the expansion of the mineral sources may be associated with the involvement of substandard mining dumps [12] and tailings stored in the tailings pond (old tailings) in the processing.

\section{Materials and Methods}

The tailings slurry of the flotation concentrating factory is discharged into the tailings pond. The distribution by size and content of the main elements in the tailings is presented in Table 1. The sample was taken from the tailings sump at PCF. Recovery of scheelite into the final standard concentrate was $86.5 \%$, chalcopyrite into copper concentrate $-65 \%$.

Table 1. Sieve characteristics of the sample of the current final tailings at PCF

\begin{tabular}{|c|c|c|c|c|c|c|c|c|c|c|c|}
\hline \multirow{2}{*}{$\begin{array}{c}\text { Size } \\
\text { classes, } \\
\text { microns }\end{array}$} & \multirow{2}{*}{$\begin{array}{c}\text { Yield, } \\
\text { \% }\end{array}$} & & \multicolumn{2}{|c|}{ Mass fraction, \% } & \multicolumn{2}{c|}{ Content, g/ t } & \multicolumn{6}{|c|}{ Recovery, \% } \\
\hline+250 & 4.69 & 0.05 & 0.037 & 0.03 & 0.96 & 0.22 & 2.66 & 3.05 & 4.62 & 2.53 & 2.15 \\
\hline$-250+160$ & 8.92 & 0.04 & 0.051 & 0.06 & 1.12 & 0.21 & 4.05 & 8.00 & 8.38 & 5.62 & 6.94 \\
\hline Total & 13.61 & 0.04 & 0.046 & 0.048 & 1.06 & 0.21 & 6.72 & 11.05 & 13.00 & 8.15 & 9.08 \\
\hline$-160+80$ & 27.42 & 0.03 & 0.040 & 0.056 & 1.2 & 0.24 & 9.35 & 19.29 & 29.44 & 18.50 & 21.32 \\
\hline$-80+15$ & 37.55 & 0.037 & 0.037 & 0.09 & 1.65 & 0.24 & 15.79 & 24.44 & 40.32 & 34.83 & 46.40 \\
\hline$-15+0$ & 21.42 & 0.28 & 0.12 & 0.078 & 3.20 & 0.18 & 68.15 & 45.21 & 17.25 & 38.53 & 23.20 \\
\hline Total $-80+0$ & 58.97 & 0.13 & 0.067 & 0.085 & 2.21 & 0.22 & 83.93 & 69.65 & 57.56 & 73.36 & 69.60 \\
\hline Final tailings & 100 & 0.088 & 0.057 & 0.072 & 1.78 & 0.22 & 100 & 100 & 100 & 100 & 100 \\
\hline
\end{tabular}

The average content of valuable components in the tailings pond according to the commodity balance is as follows: $\mathrm{WO}_{3}-0.11 \%, \mathrm{Cu}-0.09 \%, \mathrm{Au}-0.76 \mathrm{~g} / \mathrm{t}, \mathrm{Ag}-1.65 \mathrm{~g} /$ $\mathrm{t}$; mass fraction of class $-80+0 \mu \mathrm{m}-56-60 \%$; pulp density $-2.5-3.0 \mathrm{~g} / \mathrm{cm}^{3}$.

The feed for testing the washability of old tailings at PFC is represented by a sample taken from a winter reclamation ditch (in 2017) at a depth of $2 \mathrm{~m}$. There was no liquid phase in the sample, its weight was $100 \mathrm{~kg}$. The average mass fraction was, $\%$ : $\mathrm{WO}_{3}-0.08$ (variation limits for individual samples 0.046-0.10), $\mathrm{Cu}-0.052(0.017-0.078), \mathrm{S}-2.04$, As $-0.054, \mathrm{P}-0.13, \mathrm{CaCO}_{3}-5.8$; the average Au content being $0.38 \mathrm{~g} / \mathrm{t}, \mathrm{Ag}-1.1 \mathrm{~g} / \mathrm{t}$. The average mass fraction of the size class $-80+0 \mu \mathrm{m}$ in the sample was $23 \%$.

Drainage of the liquid phase of the pulp through the sands (at a depth of $2 \mathrm{~m}$ ) led to a decrease in the content of valuable components in the sample by $50-66 \%$ and an increase in the size of the material. Therefore, further the initial sample of old tailings will be referred to as the sand fraction of old tailings (SFOT).

Mineral composition of SFOT, expressed by mass fraction in $\%$ is as follows: pyroxene -40 , quartz -35 , biotite -10 , calcite -5.5 , sulfides -4.5 , feldspars -3 , other minerals (amphibole, epidote, muscovite, limonite, apatite, scheelite) - 2. Contents of scheelite and chalcopyrite, their associations with minerals by size classes are presented in Table 2.

In the class of $-500+250 \mu \mathrm{m}$, open intergrowths of scheelite with quartz, less often with pyroxene, those of chalcopyrite with pyrrhotite, less often with quartz were observed; the 
grain size of valuable minerals was $0.01-0.03 \mathrm{~mm}$. With a decrease in the size of the tailings, closed intergrowths of a fine placer of scheelite appear in quartz, less often in sulfides; chalcopyrite is characterized by complex Po-Q-Cp intergrowths, rare Cp-Ars intergrowths occur, grain size being less than $0.01 \mathrm{~mm}$.

Table 2. Contents and associations of scheelite and chalcopyrite in the average sample of the sand fraction of old tailings by size class

\begin{tabular}{|c|c|c|c|c|c|c|c|c|c|}
\hline \multirow{2}{*}{$\begin{array}{c}\text { Size } \\
\text { classes, } \\
\text { microns }\end{array}$} & \multirow[t]{2}{*}{$\begin{array}{r}\text { Yield, } \\
\%\end{array}$} & \multicolumn{2}{|c|}{$\begin{array}{r}\text { Mass fraction, } \\
\%\end{array}$} & \multicolumn{2}{|c|}{ Recovery, \% } & \multicolumn{2}{|c|}{$\begin{array}{r}\text { Mass share of } \\
\text { intergrowths, \% }\end{array}$} & \multicolumn{2}{|c|}{$\begin{array}{r}\text { Associations } \\
\text { with minerals }\end{array}$} \\
\hline & & Shl & Cp & Shl & Cp & Shl & Cp & Shl & Cp \\
\hline$-500+250^{*}$ & 17.76 & 0.060 & 0.13 & 11.72 & 16.61 & $95-90$ & 100 & $\mathrm{Q}, \mathrm{Px}$ & Po, Q \\
\hline$-250+160$ & 20.18 & 0.054 & 0.12 & 11.98 & 17.42 & $50-65$ & $60-70$ & $\mathrm{Q}, \mathrm{Px}$, & Po, Q, \\
\hline$-160+80$ & 39.04 & 0.104 & 0.17 & 44.65 & 47.75 & $5-10$ & $25-30$ & Po & Ars \\
\hline$-80+0$ & 23.02 & 0.125 & 0.11 & 31.65 & 18.22 & - & - & - & \\
\hline Total & 100 & 0.091 & 0.14 & 100 & 100 & & & & \\
\hline
\end{tabular}

${ }^{*}$ The percentage of grain size +500 microns in the sample is $0,15 \%$. Mass fraction of $\mathrm{WO}_{3}-0,073 \%, \mathrm{Cu}-$ $0,048 \%$. Abbreviations: Shl — scheelite, $\mathrm{Cp}$ - chalcopyrite, Q — quartz, Px — pyroxene, Po — pyrrhotite, Ars - arsenopyrite.

To assess flotation, a sample of the sand fraction of old tailings was ground in a laboratory ball mill at the ratio S:L:Me $=1(\mathrm{~kg}): 600(\mathrm{ml}): 8(\mathrm{~kg})$, grinding time being 15 minutes. As a result, the proportion of grains of flotation size in the flotation feed increased, the distribution of target minerals in intergrowths decreased, and the mineral surface was activated due to the removal of surface films. After regrinding, the mass fraction of the flotation class $-80+0 \mu \mathrm{m}$ in the flotation feed was $58 \%$. The distribution of tungsten trioxide and copper was $73 \%$ and $75 \%$, respectively.

Flotation of scheelite and chalcopyrite from crushed SFOT samples was carried out in laboratory machines - mechanical flotation machine Mekhanobr (chamber volume 31 , sample weight $1 \mathrm{~kg}$ ) and Pneuflot ${ }^{\circledR}$ (contact tank volume 601 , chamber volume 12.51 , sample weight $15 \mathrm{~kg}$ ) - using circulating water. Commercial Pneuflot ${ }^{\circledR}$ machines can beneficiate less than $0.3 \mathrm{~mm}$ ore material without regrinding. The content of rough matter in circulating water was $4.5 \mathrm{~g} / \mathrm{l}, \mathrm{pH}=8.7$. The flotation scheme included main sulphide flotation $(10 \mathrm{~min})$, rough scheelite flotation and two control flotations with a total time of $15 \mathrm{~min}$. The pulp $\mathrm{pH}$ modifiers were not fed to the sulfide flotation; dialkyldithiophosphate IMA-I413p (25 g/t) was used as a collector, pine oil $(20 \mathrm{~g} / \mathrm{t})$ was used as a foaming agent, and water glass $(100 \mathrm{~g} / \mathrm{t})$ was introduced to reduce the loss of scheelite with sulfides. Scheelite cycle reagent mode: soda $-3.6 \mathrm{~kg} / \mathrm{t}(\mathrm{pH}=10.4$, pulp hardness $-0.96 \mathrm{mg}$-eq/l), water glass $-350 \mathrm{~g} / \mathrm{t}$, sodium oleate of technical acid B-115 - 250+50+25 g/t; pulp temperature during conditioning with reagents $28^{\circ} \mathrm{C}$.

Testing of the enrichment parameters according to the combined scheme was carried out on a laboratory gravity table and Mekhanobr V-3(1.0)-0.5 (0.3-0.1) 1 flotation machines.

The Pneuflot ${ }^{\circledR}$ laboratory unit was installed at the industrial site of PCF. Grinding of kilogram samples to a size of $58 \%$ of the class $-80+0 \mu \mathrm{m}$ and comparative experiments on a laboratory mechanical machine were carried out in a research laboratory using circulating water.

It was expedient to compare the washing capacity of the sand fraction of old tailings and the washing capacity of final tailings from the tailings sump. When testing in a Pneuflot ${ }^{\circledR}$ machine, a sample of the sand fraction was diluted with circulating water. In the contact tank, the slurry volume was 56 liters at $24.4 \%$ solids. Additionally (to eliminate the possibility of clogging of the power supply nozzles), circulating water was introduced into the chamber of the flotation machine with a volume of 4 liters. The tailings sample was transferred to the contact tank without dilution. 


\section{Results and Discussion}

The results of flotation are presented in Table 3. Testing consisted of two runs in each batch. The best results are given.

Table 3. Parameters of concentration of final tailings of PCF and SFOT sample

\begin{tabular}{|c|c|c|c|c|c|c|}
\hline \multirow[t]{2}{*}{ Product } & \multicolumn{3}{|c|}{ Pneuflot $^{\circledR}$ floatation machine } & \multicolumn{3}{|c|}{ Mekhanobr mechanical machine } \\
\hline & $\begin{array}{c}\text { Yield, } \\
\%\end{array}$ & $\begin{array}{c}\text { Mass } \\
\text { fraction of } \\
\mathrm{WO}_{3}, \%\end{array}$ & $\begin{array}{c}\text { Recovery of } \\
\mathrm{WO}_{3}, \%\end{array}$ & $\begin{array}{c}\text { Yield, } \\
\%\end{array}$ & $\begin{array}{c}\text { Mass } \\
\text { fraction of } \\
\mathrm{WO}_{3}, \%\end{array}$ & $\begin{array}{c}\text { Recovery of } \\
\mathrm{WO}_{3}, \%\end{array}$ \\
\hline \multicolumn{7}{|c|}{ Test 10, floatation feed being PCF final tailings (sampling point is tailings sump) } \\
\hline $\begin{array}{l}\mathrm{WO}_{3} \text { rough } \\
\text { floatation } \\
\text { concentrate }\end{array}$ & 4.70 & 0.20 & 10.42 & 1.89 & 0.22 & 4.70 \\
\hline Tailings & 95.30 & 0.083 & 89.58 & 97.01 & 0.085 & 93.30 \\
\hline S-concentrate & - & & - & 1.10 & 0.16 & 1.99 \\
\hline Total & 100 & 0.088 & 100 & 100 & 0.088 & 100 \\
\hline \multicolumn{7}{|c|}{ Test 11, floatation feed being SFOT } \\
\hline $\begin{array}{l}\mathrm{WO}_{3} \text { rough } \\
\text { floatation } \\
\text { concentrate }\end{array}$ & 8.17 & 0.60 & 69.43 & 5.93 & 0.62 & 52.45 \\
\hline Tailings & 90.42 & 0.022 & 28.17 & 87.50 & 0.03 & 37.29 \\
\hline S-concentrate & 1.41 & 0.12 & 2.40 & 6.57 & 0.11 & 10.26 \\
\hline Total & 100 & 0.071 & 100 & 100 & 0.070 & 100 \\
\hline
\end{tabular}

The absence of sulphide flotation and the extremely low recovery of scheelite from the tailing pulp is associated with a high residual concentration of water glass $-2.5-3 \mathrm{~g} / 1, \mathrm{pH}$ $=9.9$ (in the process flow diagram of PCF enrichment, the upgrading of rough scheelite concentrates is performed using the Petrov method).

The best results in the flotation of scheelite from the sand fraction were obtained in the Pneuflot ${ }^{\circledR}$ flotation machine. With a concentration degree of 8.5 in the enriched product, the scheelite recovery was $69 \%$. Table 4 shows that a rough concentrate with a mass fraction of $\mathrm{WO}_{3}$ of $0.62 \%$ and an extraction of scheelite of $52.5 \%$ was separated in a laboratory mechanical machine. A significant proportion of scheelite losses (22\% of total losses) are associated with sulfide concentrate. In a mechanical engine, sulfides floated more actively. The yield of sulfide concentrate was $6.6 \%$, the mass fraction of $\mathrm{Cu}-0.48 \%$, $\mathrm{S}-22.5 \%$, As $-0.24 \%$, copper recovery $-65.7 \%$. Fine scheelite less than 44 microns in size is lost with sulfides. By introducing two cleaners (chamber volume $0.5-0.21$ ) of sulfide concentrate, it is possible to reduce the loss of scheelite with sulfides to $2.11 \%$ while recovering $45 \%$ copper with a mass fraction of $\mathrm{Cu} 0.83 \%$. With the introduction of sulfide middlings into the scheelite cycle, a rough concentrate was obtained with a mass fraction of $\mathrm{WO}_{3} 0.47 \%$ and the recovery of $59.7 \%$.

In the Pneuflot ${ }^{\circledR}$ machine, sulphide flotation was practically absent; the recovery of copper into sulphide concentrate was $9.5 \%$ with its mass fraction of $0.32 \%$.

The quality of the enriched scheelite product obtained from the sand fraction of old tailings corresponds to the quality of the feed for the rough scheelite flotation at PCF, which allows integrating it with the PCF's process flow diagram.

The sieve performance of the tailings of the Pneuflot ${ }^{\circledR}$ cell is shown in Table 4. 
Table 4. Distribution of scheelite by size class in Pneuflot ${ }^{\mathbb{R}}$ tailings

\begin{tabular}{|c|c|c|c|c|c|c|}
\hline \multirow{2}{*}{$\begin{array}{l}\text { Size classes, } \\
\text { microns }\end{array}$} & \multirow{2}{*}{$\begin{array}{c}\text { Yield, } \\
\%\end{array}$} & \multirow{2}{*}{$\begin{array}{c}\text { Mass } \\
\text { fraction of } \\
\mathrm{WO}_{3}, \%\end{array}$} & \multicolumn{3}{|c|}{ Distribution in tailings, \% of } & \multirow{2}{*}{$\begin{array}{c}\text { Recovery to } \\
\text { concentrate, } \\
\% \text { of size } \\
\text { class }\end{array}$} \\
\hline & & & product & $\begin{array}{c}\text { primary } \\
\text { floatation } \\
\text { feed }\end{array}$ & class & \\
\hline+160 & 2.61 & 0.015 & 2.00 & 0.55 & 42.0 & 58.0 \\
\hline$-160+80$ & 40.56 & 0.018 & 37.67 & 10.31 & 44.0 & 56.0 \\
\hline$-80+44$ & 19.84 & 0.016 & 17.11 & 4.68 & 22.4 & 77.6 \\
\hline$-44+15$ & 24.12 & 0.014 & 17.60 & 4.81 & 17.9 & 82.1 \\
\hline$-15+0$ & 12.87 & 0.038 & 25.62 & 7.01 & 25.5 & 74.5 \\
\hline Total & 100 & 0.019 & 100 & 27.36 & - & - \\
\hline
\end{tabular}

Flotation of SFOT in Pneuflot ${ }^{\circledR}$ showed the possibility of separating scheelite into a concentrated primary flotation concentrate from material with a size of $-44+15$ microns by $82 \%$, and with a size of $-15+0$ microns (from sludge) by $75 \%$ of the class, for the mechanical machine (volume 31 ) $-77 \%$ and $49 \%$ of the class, respectively. The design of the Pneuflot ${ }^{\circledR}$ flotation machine made it possible to increase the efficiency of scheelite flotation from sludge by 1.5 times. These studies on flotation made it possible to assess the flotation capacity of the tailing dump materials; however, industrial enrichment of raw stock with such a low initial content of valuable minerals is economically inexpedient. The combined gravity-flotation scheme of SFOT processing has been studied. The results of enrichment of scheelite and chalcopyrite on a laboratory concentration table are presented in Table 5 .

Table 5. Distribution of valuable components by SFOT gravity products

\begin{tabular}{|c|c|c|c|c|c|}
\hline \multirow{2}{*}{ Products } & \multirow{2}{*}{$\begin{array}{c}\text { Yield, } \\
\mathbf{\%}\end{array}$} & \multicolumn{2}{|c|}{ Mass fraction, \% } & \multicolumn{2}{c|}{ Recovery, \% } \\
\cline { 3 - 6 } & & $\mathbf{W O}_{\mathbf{3}}$ & $\mathbf{C u}$ & $\mathbf{W O}_{\mathbf{3}}$ & $\mathbf{C u}$ \\
\hline Gravity concentrate & 1.14 & 4.07 & 0.063 & 58.01 & 1.37 \\
\hline Middling of re-cleaning 2 & 2.87 & 0.17 & 0.12 & 6.12 & 6.60 \\
\hline Total combined gravity product & 4.01 & 1.28 & 0.10 & 64.13 & 7.97 \\
\hline Middling of re-cleaning 1 & 37.07 & 0.039 & 0.074 & 18.13 & 52.54 \\
\hline Gravity tailings & 58.92 & 0.024 & 0.035 & 17.74 & 39.49 \\
\hline Total SFOT & 100 & 0.080 & 0.052 & 100 & 100 \\
\hline
\end{tabular}

With the help of gravity concentration on the concentration table, it is possible to separate $4 \%$ of SFOT into a combined gravity product with a mass fraction of $\mathrm{WO}_{3}-$ $1.28 \%$, and scheelite recovery at $64 \%$. Chalcopyrite is redistributed to the middling product of the first cleaning and tailings.

The results of enrichment for impurities on a laboratory concentration table are presented in Table 6.

Table 6. Distribution of impurities in SFOT gravity products

\begin{tabular}{|c|c|c|c|c|c|c|c|c|c|}
\hline Products & $\begin{array}{c}\text { Yield, } \\
\%\end{array}$ & \multicolumn{4}{|c|}{ Mass fraction, \% } & \multicolumn{5}{c|}{ Recovery, \% } \\
\cline { 3 - 11 } & & $\mathrm{P}$ & $\mathrm{Ca}$ & $\mathrm{S}$ & $\mathrm{As}$ & $\mathrm{P}$ & $\mathrm{Ca}$ & $\mathrm{S}$ & $\mathrm{As}$ \\
\hline $\begin{array}{c}\text { Gravity } \\
\text { concentrate }\end{array}$ & 1.14 & 0.79 & 0.72 & 27.98 & 4.21 & 6.80 & 0.14 & 15.59 & 88.04 \\
\hline $\begin{array}{c}\text { Middling of re- } \\
\text { cleaning 2 }\end{array}$ & 2.87 & 0.17 & 3.77 & 17.22 & 0.18 & 3.69 & 1.86 & 24.23 & 9.51 \\
\hline $\begin{array}{c}\text { Total combined } \\
\text { gravity product }\end{array}$ & 4.01 & 0.35 & 2.90 & 20.27 & 1.32 & 10.49 & 2.00 & 39.82 & 97.55 \\
\hline $\begin{array}{c}\text { Middling of re- } \\
\text { cleaning 1 }\end{array}$ & 37.07 & 0.16 & 7.79 & 2.31 & 0.002 & 44.90 & 49.51 & 41.98 & 1.36 \\
\hline Gravity tailings & 58.92 & 0.10 & 4.8 & 0.63 & 0.001 & 44.61 & 48.49 & 18.20 & 1.08 \\
\hline Total SFOT & 100 & 0.13 & 5.83 & 2.04 & 0.054 & 100 & 100 & 100 & 100 \\
\hline
\end{tabular}

Mass share of $\mathrm{P}$ is $1.1 \%$, As $-0.052 \%, \mathrm{~S}-0.35 \%, \mathrm{CaCO}_{3}-4.3 \%$. 
In terms of the mass fraction of apatite and calcite, the combined gravity product corresponds to the current PCF's ore. An increased content of pyrrhotite and arsenopyrite is noted. In the flotation cycle in a closed experiment, the final conditioned scheelite concentrate with a mass fraction of $\mathrm{WO}_{3}$ of $71 \%$, recovery from feed at $89 \%$ was isolated from $6 \mathrm{~kg}$ weighed portions of the combined gravity product according to the PCF's technological scheme. The results are shown in Table 7.

Table 7. Results of flotation of valuable components of the gravity product

\begin{tabular}{|c|c|c|c|c|c|}
\hline \multirow{2}{*}{ Products } & \multirow{2}{*}{$\begin{array}{c}\text { Yield, } \\
\text { \% }\end{array}$} & \multicolumn{2}{|c|}{ Mass fraction, \% } & \multicolumn{2}{c|}{ Recovery, \% } \\
\cline { 3 - 6 } & 1.56 & $\mathbf{W O}_{\mathbf{3}}$ & $\mathbf{C u}$ & $\mathbf{W O}_{\mathbf{3}}$ & $\mathbf{C u}$ \\
\hline $\mathrm{WO}_{3}$ concentrate & 70.88 & 0.010 & 89.29 & 0.15 \\
\hline Upgraded tailings & 4.98 & 0.96 & 0.011 & 3.84 & 0.54 \\
\hline Drainage & 0.09 & 9.1 & 0.055 & 0.67 & 0.05 \\
\hline Total rough concentrate & 6.63 & 17.55 & 0.012 & 93.80 & 0.74 \\
\hline Cu concentrate & 41.06 & 0.098 & 0.022 & 3.23 & 8.59 \\
\hline Copper tailings & 0.60 & 0.11 & 8.30 & 0.05 & 47.85 \\
\hline Total S concentrate & 51.71 & 0.07 & 0.086 & 2.92 & 42.82 \\
\hline $\begin{array}{c}\text { Combined gravity } \\
\text { product }\end{array}$ & 52.31 & 0.07 & 0.18 & 2.97 & 90.67 \\
\hline & 100 & 1.24 & 0.10 & 100 & 100 \\
\hline
\end{tabular}

The performed volume of research allows calculating the indicators of the combined scheme of SFOT processing. Data are presented in the diagram (Fig. 1).

\begin{tabular}{|c|c|c|}
\hline $\mathbf{Y}$ & $\boldsymbol{B}$ & $\boldsymbol{\varepsilon}$ \\
\hline \multicolumn{4}{|c|}{$*$} \\
\hline
\end{tabular}

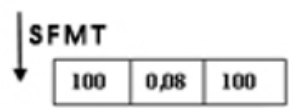

Rough concentration on table.

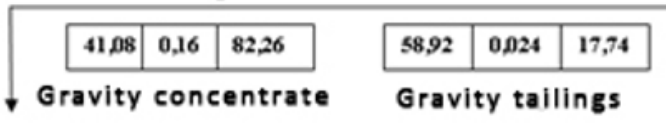

Cleaning 1 of gravity concentrate

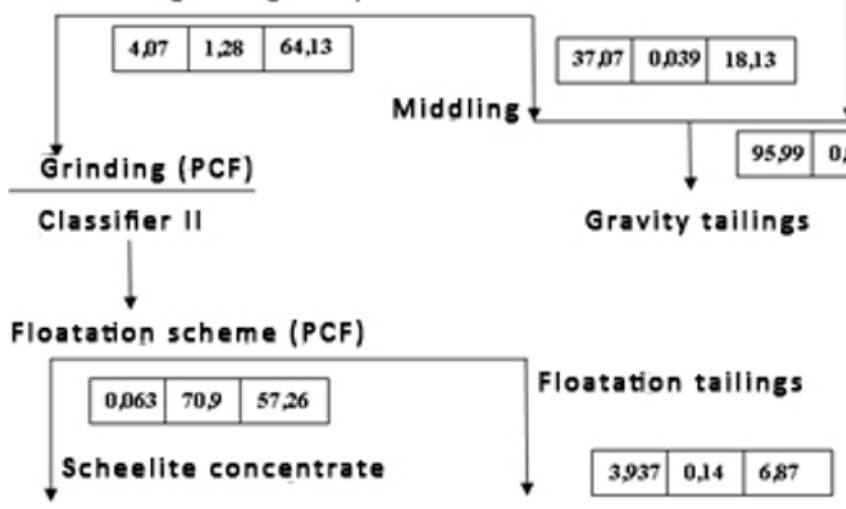

Fig. 1. Combined scheme of processing SFOT at PCF

\section{Conclusions}

The possibility of processing old tailings of Primorsky Concentrating Factory has been assessed. A comparison of flotation concentration of SFOT using a laboratory mechanical machine and a Pneuflot ${ }^{\circledR}$ floatation machine was made. The recovery of scheelite at the same degree of concentration in Pneuflot ${ }^{\circledR}$ machine is $16.5 \%$ higher, due to 1.5 times more efficient sludge flotation $(-15+0 \mu \mathrm{m})$. Flotation of SFOT using Pneuflot ${ }^{\circledR}$ showed the 
possibility of separating scheelite into a concentrated primary flotation concentrate from materials with a size of $-44+15$ microns by $82 \%$, and with a size of $-15+0$ microns (from sludge) by $75 \%$ of the class, for a mechanical machine (volume 31 ) $-77 \%$ and $49 \%$ of the class, respectively. The quality of the enriched scheelite product obtained from the sand fraction of old tailings meets the requirements for rough scheelite flotation at PCF, enabling to include it in the PCF's technological scheme.

According to the combined gravity-flotation enrichment scheme, a conditioned scheelite concentrate was obtained with a mass fraction of $70.9 \% \mathrm{WO}_{3}$, throughout recovery being $57.3 \%$.

The authors are grateful to the staff of the research laboratory of Primorsky Concentrating Factory.

This study was financially supported by the RFBR Program (project No. 20-55-12002 NNIO_a).

\section{References}

1. N. Kupka, M. Rudolph International Journal of Mining Science and Technology, 28, 373-384 (2018)

2. V.I. Revnivtsev, T.G. Rybakova, E.P. Lehman, X-ray radiometric enrichment of complex ores of non-ferrous and rare metals, 120 (1990)

3. A.S. Kobzev, Radiometric beneficiation of mineral raw stock, 7-9 (2015)

4. A. Haslam, 21st ITIA Annual General Meeting, (2008)

5. E.D. Shepeta, L.A. Samatova, I.V. Alushkin, T.I. Yushina, Non-Ferrous Metals, 40, 1, 9-16, (2016)

6. Yu.P. Eremin, G.A. Denisov, M.D. Stern et al., Concentration of ores, 3, 24-28, (1981)

7. N.M. Lebedev, O. V. Voronin, S.S. Lozhnikov et al., Proceedings of the V Congress of CIS Enrichment Products, 3, 225-232 (2005)

8. N.K. Algebraistova, A.V. Makshanin, Journal of the Siberian Federal University. Engineering and Technology, 4, 283-295 (2011)

9. V.A. Ignatkina, Journal of Mining Science, 53, 5, 897-906 (2017)

10. Forss M., A. Breussand, T. Monreden, A.A. Grebenschikov. Mining Industry, 5, 6 (2005)

11. A.V. Lebedok, Concentration of ores, 4, 17-20 (2018)

12. E.D. Shepeta, L.A. Samatova, O.V. Voronova, Mining Journal, 10, 67-71 (2018)

13. J.N. Kohmuench, M.J. Mankosa, CPSA Journal CPSA Journal, 5, 1 (2006)

14. J.N. Kohmuench, M.J. Mankosa, E.S. Yan, XVI International coal preparation congress, 374-381 (2010)

15. V.A. Kozlov, M.F. Pikalov, Coal, 2, 65-69 (2014)

16. L. Markworth, W. Jaspers, A. Arkhipov, Flotation conference, (2005)

17. L. Markworth, W. Jaspers, A. Arkhipov, Gornaya Promyshlennost, 6, 20-22 (2005)

18. L. Markworth, N. Chevga, XVIII International coal preparation congress, 1033-1034 (2016)

19. C. Li, Z. Gao, Powder Technology, 322, 386-392 (2017)

20. N. Kupka, M. Rudolph, Proc. of mineral engineering conference, (2017)

21. R.J. Compañero, Proc. of MVTAT, (2016)

22. A.A. Abramov, Flotation concentration methods, 4, 3, 550 (2008)

23. V.I. Melik-Gaikazyan, N.P. Emelyanova, Z. I. Glazunov, Concentration of ores, 1, 2531 (1976)

24. S.I. Chernykh, Creation of pneumatic-type flotation machines and experience of their use at concentration plants, 300 (1995) 